\title{
Change Detection of Lake Chad Water Surface Area Using Remote Sensing and Satellite Imagery
}

\author{
Abdel-Aziz Adam Mahamat' ${ }^{1}$, Adeeba Al-Hurbann ${ }^{2 *}$, Nehaya Saied ${ }^{2}$ \\ ${ }^{1}$ Integrated International for Environmental Services (IIES), Kuwait City, Kuwait \\ ${ }^{2}$ Earth and Environmental Sciences Department, Faculty of Science, Kuwait University, Kuwait City, Kuwait \\ Email: adamasabdul@gmail.com, ^q8geo@hotmail.com, *adeeba.alhurban@ku.edu.kw, \\ nonna2001@hotmail.com, nihaia.said@ku.edu.kw
}

How to cite this paper: Mahamat, A.-A.A., Al-Hurban, A. and Saied, N. (2021) Change Detection of Lake Chad Water Surface Area Using Remote Sensing and Satellite Imagery. Journal of Geographic Information System, 13, 561-577.

https://doi.org/10.4236/jgis.2021.135031

Received: August 14, 2021

Accepted: September 27, 2021

Published: September 30, 2021

Copyright $\odot 2021$ by author(s) and Scientific Research Publishing Inc. This work is licensed under the Creative Commons Attribution International License (CC BY 4.0).

http://creativecommons.org/licenses/by/4.0/

\begin{abstract}
The Lake Chad located in the west-central Africa in the Sahel region at the edge of the Sahara experienced severe drought during 1970s and 1980s and overexploitation (unintegrated and unsustainable use), which is a result of variant land uses and water management practices during the last 50 years. This resulted in a decline of the water level in the Lake and surrounding rivers. The present study analyzed satellite images of Lake Chad from Landsat-MSS, Landsat-OLI to investigate the change of the open water surface area during the years of 1973, 1987, 2001, 2013, and 2017. Supervised classifications were performed for the land cover analysis. The open water area in 1973 was covering $16,157.34 \mathrm{~km}^{2}$ approximately, and that was $64.6 \%$ of the total lake area in the 1960s. As an ultimate result of the extreme drought that the study area witnessed through 1970s-1980s, the open water area has decreased to $1831.44 \mathrm{~km}^{2}$, i.e. around $11.33 \%$, compared to that in 1973 . The dilemma that the study area is suffering from is believed to be a catastrophic complication of the aforementioned drought crisis, which arose as an ultimate result the climate change, global warming, and the unintegrated and unsustainable use of water challenges the study area is still encountering.
\end{abstract}

\section{Keywords}

Satellite Imagery, Landsat, Remote Sensing, GIS, Drought, Overexploitation

\section{Introduction}

Fresh water on earth surface is less than $2.5 \%$ of the total global water [1]. It comes in form of ice, glaciers, lakes, rivers, etc. With the high population gross 
that our world faces, the demand for water had remarkably increased to meet the domestic, agricultural, and industrial challenges, which led to the scarcity of fresh water as a natural resource in many places on the earth. Climate change and variation in the land use nowadays have considerably contributed to the exaggeration of such a dilemma.

Lake Chad provides significant fish stocks, vital habitat for many species in the Sahel corridor, as well as, major water source for farmlands and grazing areas [2]. Lake Chad basin is one among many regions that have been affected by the climate changes and water unintegrated and unsustainable use in the world. Lake Chad problem had attracted the international attention after the dramatic decrease (more than $90 \%$ ) of its surface area in less than 50 years (from $25,000 \mathrm{~km}^{2}$ in 1963 to less than $2500 \mathrm{~km}^{2}$ in mid 1980s) [3]. The shrinkage of the lake surface area can be attributed to many factors, such as climate change, overgrazing, and the water resources unintegrated and unsustainable use, in addition to the absence of an environmental legislation that can organize the use of the lake resources. But the dramatic regression of the lake in the 1970s-1980s is considered to be a direct consequence of the drought that hit the African Sahel belt during that period. The drought was extremely severe that despite the observed increase in rainfall averages the lake still suffering from its consequence. Such drought periods had led to significant changes in the characteristics of the lake area [2]. Lake Chad crisis was on the agenda three times during the COP 21 Global change summit in Paris 2015 [4].

Due to the relative unavailability of ground stations providing monitoring meteorological database that would provide a comprehensive vision on the relation of the decline in the rainfall and the water discharge feeding Lake Chad, in addition to the deficiency of the available data in concern throughout the study indicated period (1973-2017), this paper found that GIS and remote sensing data through using satellite images acquired by Landsat during (1973-2017) to be a proper method to detect and estimate the changes in the water surface area and the lake's boundary throughout the study period, as well as finding the relation between the shrinkage in the water surface area of the lake and the drought periods the area witnessed being believed as the major cause of such a dilemma beside the anthropogenic activities and strategies in water and landuse. In addition, this paper investigates the correlation between hydroclimatic and the fluctuation of the lake's surface area.

\section{Study Area}

The Lake Chad is located in the west-central Africa in the Sahel region at the edge of the Sahara. It is located between Latitudes $12^{\circ} 0^{\prime} \mathrm{N}$ and $14^{\circ} 20^{\prime} \mathrm{N}$ and Longitudes $13^{\circ} 0^{\prime} \mathrm{E}$ and $15^{\circ} 20^{\prime} \mathrm{E}$. The lake shares border with four countries (Chad, Cameroon, Niger, and Nigeria) (Figure 1).

\subsection{Climate}

The lake is located in a semi-arid zone. The average rainfall in the basin is 320 


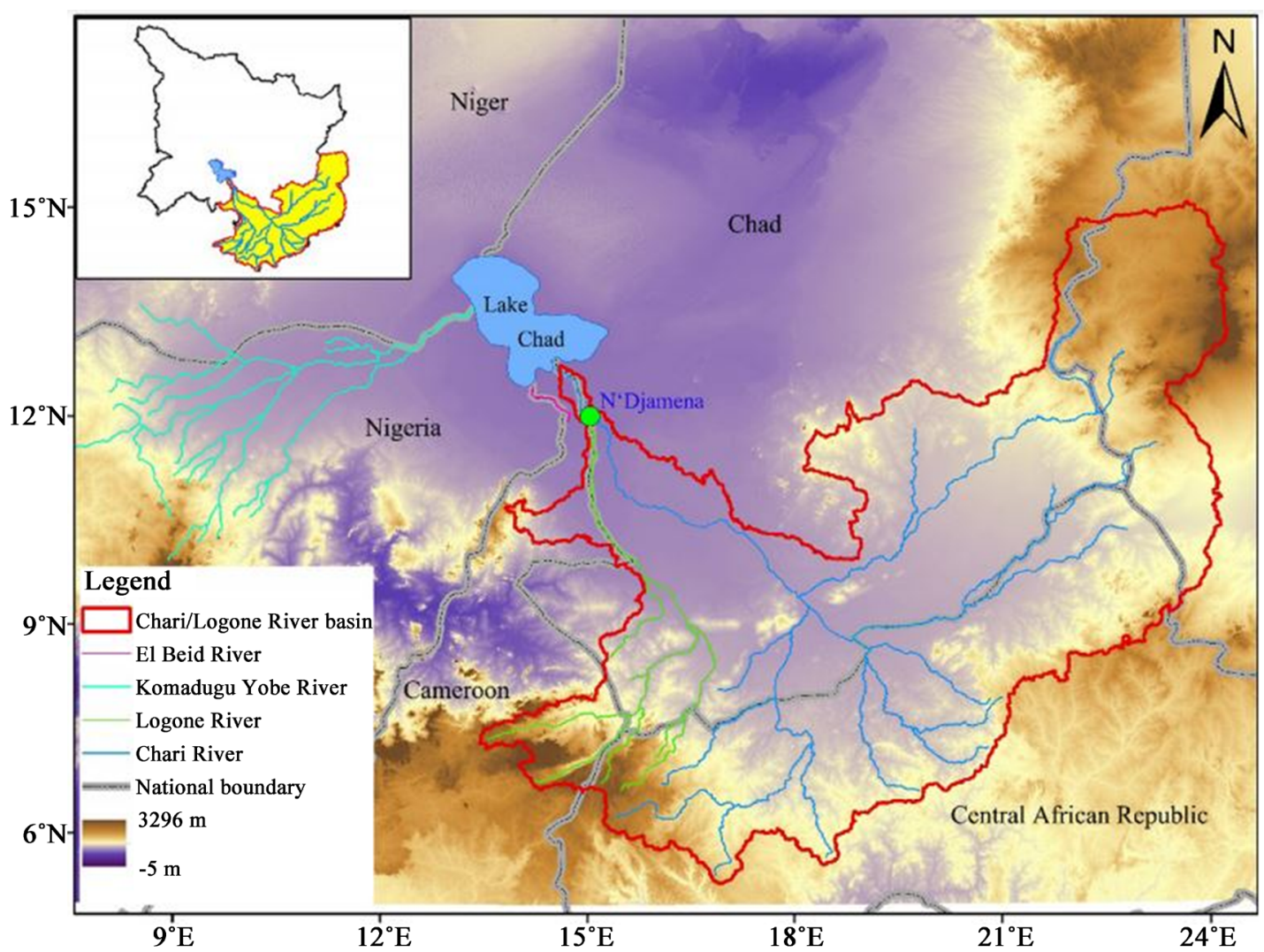

Figure 1. Location map of the study area (after [5]).

$\mathrm{mm}$ and reaches more than $1500 \mathrm{~mm}$ in the southern part and less than $100 \mathrm{~mm}$ in the northern part of the basin. The rainfall is monsoonal, and $90 \%$ of the rainfall is precipitating during June to October, which is considered as a wet season. The average temperature is $21.4^{\circ} \mathrm{C}$ and reaches $35^{\circ} \mathrm{C}-40^{\circ} \mathrm{C}$ in the northern part of the basin. The basin is exposed to high evaporation rate that reaches $2200 \mathrm{~mm}$ during summer season. The dominant winds are the Harmattan winds from November to April [6].

\subsection{Hydrology}

Lake Chad receives its water mainly from the Chari and the Logone Rivers, approximately 95\%, the rest inflow comes from the Yobe River (3\%), and 2\% from direct rainfall (Figure 1) [6].

Lake Chad extent depends on the rainfall over the whole basin which flows to the lake through channels and rivers, mainly the Chari and Logon Rivers [6] [7], which means any fluctuation in the annual rainfall averages affects the lake directly.

The lake was divided into three statuses according to the volume of water in the lake [8]. These are:

1) Grand Tchad (i.e. big/large chad): the water surface area is estimated to be between $20,000 \mathrm{~km}^{2}$ to $25,000 \mathrm{~km}^{2}$ with an average depth of about $4 \mathrm{~m}$. This status of the lake is observed in the last century by Barth and Vogel in 1854, by 
Rohlfs in 1866, and by Nachtigal in 1870.

2) Normal Tchad: in this status, the water surface area covered around 18,000 $\mathrm{km}^{2}$, with an average depth of $2 \mathrm{~m}$. In this status, an archipelago of 1000 to 2000 dune islands and limited marshy vegetation could be observed along the shores.

3) Petit Tchad (i.e. small chad): This is the lake recent status. In this status, the lake is divided into two parts (northern pool and southern pool) by a shallow sill which is known by the Great Barrier locally (Figure 2). The southern pool is filled by permanent water, but the northern pool is filled by seasonal marches [9].

A new status was proposed for the lake which is called "Dry Small Lake" in which the northern pool remains dry all year long [9]. Since 1975, the lake has been fluctuating between small and dry small lake statuses [9].

\subsection{Geology and Geomorphology}

Lake Chad used to extent over a wider area (more than $350,000 \mathrm{~km}^{2}$ ) with a maximum level of $325 \mathrm{~m}$ above sea level during the Holocene; that giant lake is known by "Mega Lake Chad" (MLC) [10]. Although there are numerous evidences of existence of MLC [10] [11] [12] [13], the hypothesis that proves the existence of MLC was rejected, and a tendance was to believe that the sand ridge occurred due to a local neotectonic fault [14].

The Lake Chad basin subsurface is composed of quaternary sediments overlaying the Pliocene sediments which are underlain by Tertiary Continental Terminal sandstones. The Basin subsurface can be divided into three aquifers: the upper, the middle, and the lower aquifer; a thick layer of clay separates the quaternary and Pliocene sediments [6] [11] [15] (Figure 3(a) \& Figure 3(b)).

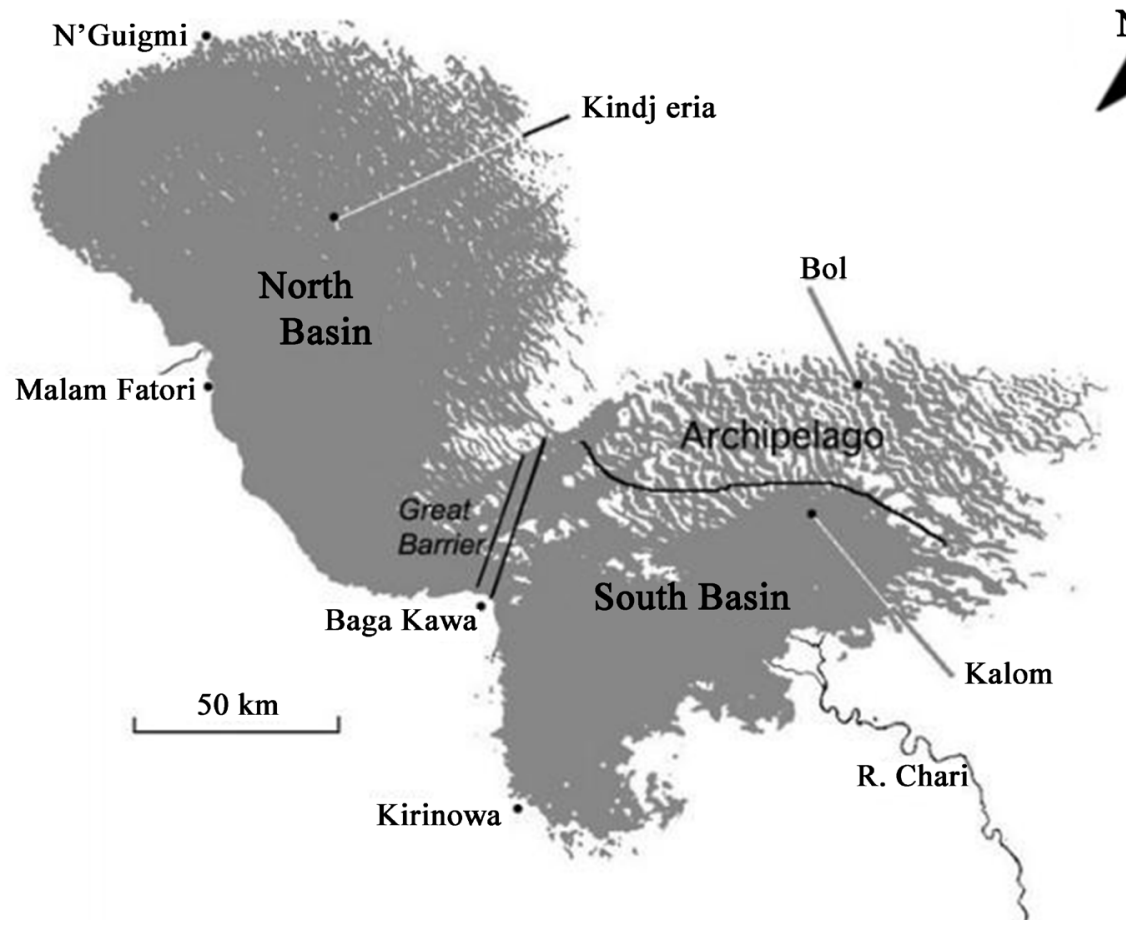

Figure 2. The Lake pools (after [8] [9]). 


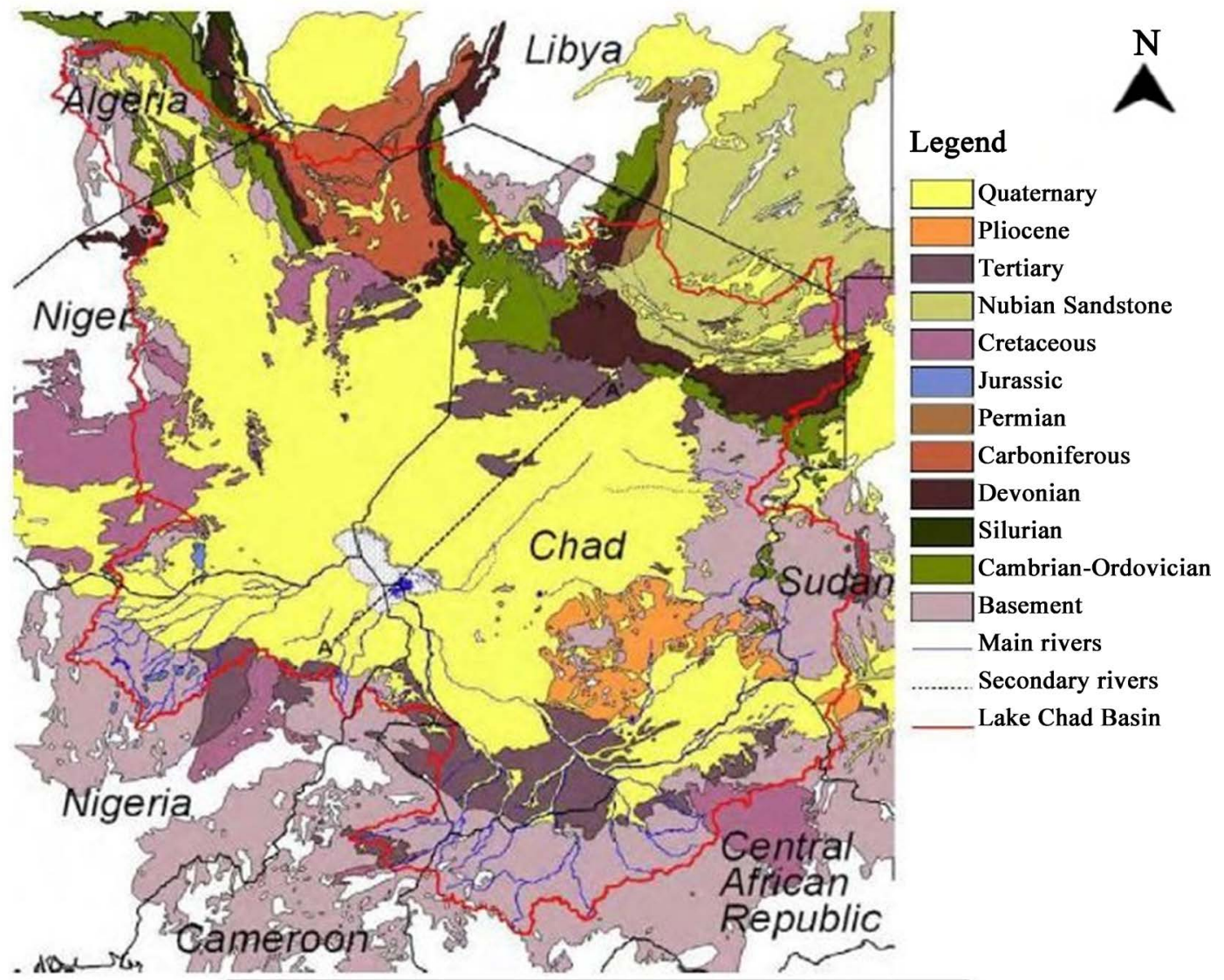

(a)

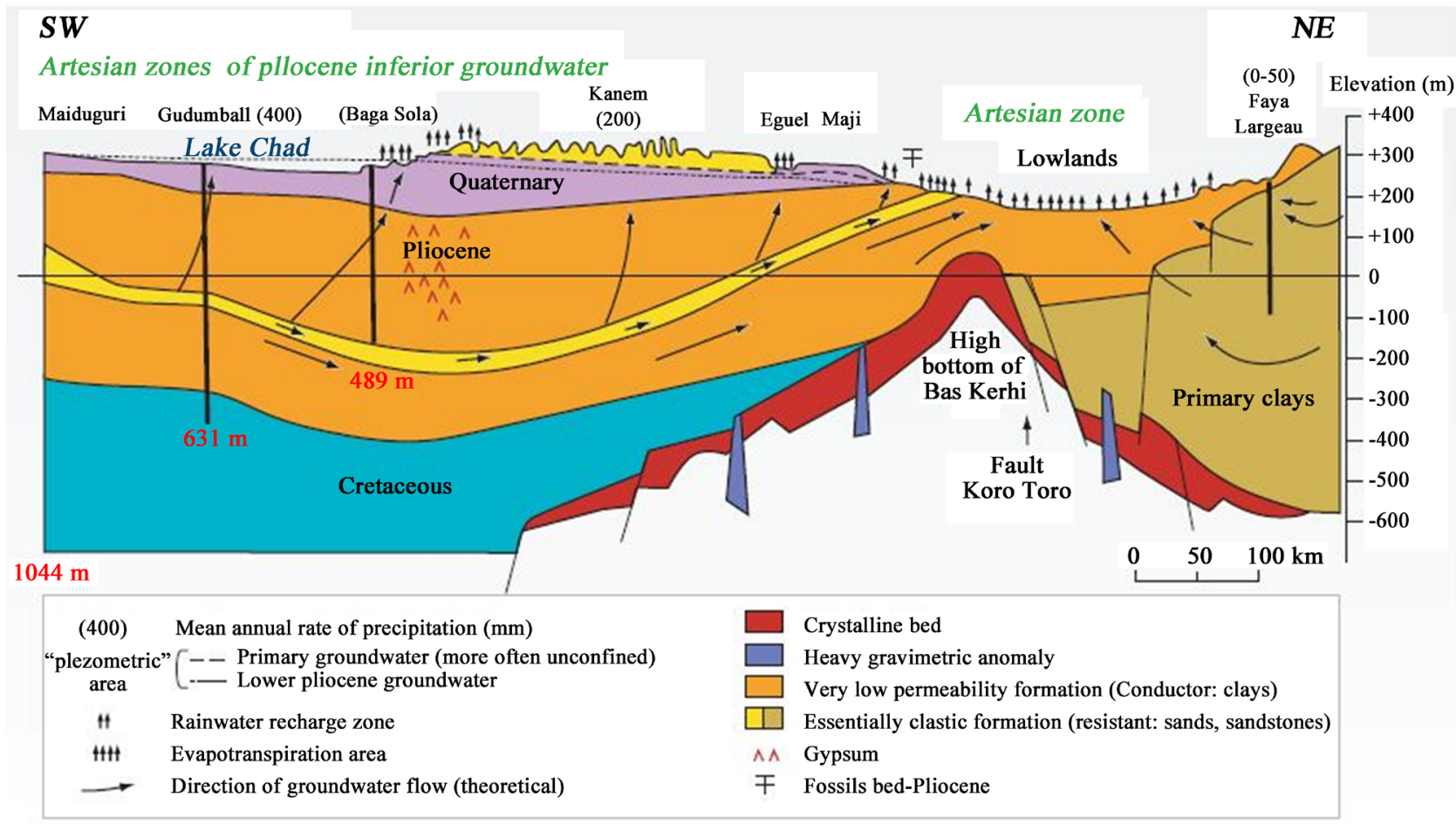

(b)

Figure 3. Geology of Lake Chad Basin (a) and the related cross-section of the basin along A-A (b) (after [15]). 
The basin is mostly covered by fine to medium sand-sized grains. The surface heights range between more than $3000 \mathrm{~m}$ above sea level in the north, north west, and the south west (Tibesti Mountains, Ahaggar Mountains, and Adamawa Plateau respectively) and around $180 \mathrm{~m}$ above sea level in the lowlands which is located in the center of the basin [16].

\section{Previous Studies}

Various papers and articles have discussed the necessity of using remote sensing data to monitor water bodies on the earth's surface. In investigating and examining Seyfe lake water surface changes for a period of 26 years, landsat satellite imagery was used [17]. The Aral sea former bottom landscape seasonal changes from were analyzed and mapped from remote sensing data [18]. [19] conducted a study in Nakuru County, which is a tropical region in the Rift Valley of Kenya in Africa where they found that when sufficient information are not available from ground stations utilizing GIS and remote sensing data using landsat satellite images for a span of years can be efficient and beneficiary in assessing water scarcity or drought periods and how it is directly related to the rainfall and precipitation amount, which are in turn directly affecting the crop yields in their study area.

Others have used multi sensor satellite data to study the dynamics of lake Trasimeno in Italy (e.g., [20]) and the ability of remote sensing data to support waterbodies monitoring and investigation was indicated [21]. There are numerous papers and researchers who have addressed the Lake Chad shrinkage. The Lake Chad water surface area had decreased in 1980s to about one tenth of its original area compared to that in 1960 s which was about $25,000 \mathrm{~km}^{2}$ [3].

In 1963 the lake decreased from 22,902 $\mathrm{km}^{2}$ to $304 \mathrm{~km}^{2}$ in 2001 [22], which means it lost about $99 \%$ of its area. The only sources found providing significant observation-based time series of area for Lake Chad are [23] [24] [25]. Their results differ significantly. $5 \mathrm{~km}$ resolution Land Surface Temperature (LST) data from the Meteo-sat satellites operated by the European Organization for the Exploitation of Meteorological Satellites (EUMETSAT) was used to develop a monthly record of the lake area from 1986 to 2001, differentiating water vs. non-water using a 2-cluster unsupervised classification process [24]. Note that this lumps dry soil, wet soil, and dry vegetation classes into a single non-water class, and water and flooded vegetation into a single water class. They avoided making the analysis during the wet season, which presumably limited misidentification of wet soil with the water classes.

They suggested that the use of satellite-based radar data may be helpful for mapping both open water and water under vegetation, but cited a number of reasons for not using it, notably the limitation of available radar data at the time of their research. They concluded that during the study period, the lake minimum size was $4600 \mathrm{~km}^{2}$ in October 1987, the maximum size was $16,300 \mathrm{~km}^{2}$ in February 2000 , the $25^{\text {th }}$ percentile area was $8800 \mathrm{~km}^{2}$, and the $75^{\text {th }}$ percentile area 
was $13,700 \mathrm{~km}^{2}$.

On the other hand, $1.1 \mathrm{~km}$ resolution Near InfraRed (NIR) data from NOAA's AVHRR on-orbit sensor was used to estimate the total lake surface water area from 1995 to 1999 [23]. The estimated frequency was sub-monthly. Based on the fact that water is absorbed strongly in the NIR part of the spectrum, whereas healthy vegetation reflects strongly in NIR, Birkett distinguished marshland and open water as the darkest pixels vs. dry land as brighter pixels. As a threshold between the two, she chose the midpoint between the two characteristic peaks of the histograms for the two types of land cover, using NIR sensor digital numbers. From that analysis, she found a permanent total water surface area (open water and marshland) of $1385 \mathrm{~km}^{2}$ and a peak total water surface area of approximately $5000 \mathrm{~km}^{2}$.

Land Surface Temperature (LST) data (dry seasons 2000-2016) from the NASA Terra MODIS sensor and EUMETSAT Meteosat-based LST measurements (dry seasons 1988-2001) from an earlier study was used, as well as, the total water surface area for Lake Chad using radar data (dry seasons 2015-2016) from the ESA Sentinel-1a mission was examined [25]. They found for the dry seasons of 1988-1989 to 2016-2017 that the maximum total water surface area of the lake was approximately $16,800 \mathrm{~km}^{2}$ (February and May, 2000), the minimum total water surface area of the lake was approximately $6400 \mathrm{~km}^{2}$ (November, 1990 ), and the average was approximately $12,700 \mathrm{~km}^{2}$. Furthermore, it was found that the total water surface area of the lake to be highly variable during this period, with an average rate of increase of approximately $143 \mathrm{~km}^{2}$ per year.

\section{Materials and Methods}

\subsection{Satellite Images Acquisition}

The data used in this paper are acquired using the Global Visualization (GloVis) web-based platform. These data are satellite images of Landsat 1 (MSS), Landsat 5 TM, Landsat 7 (ETM+), and Landsat 8 (OLI_TIRS) for the years 1973, 1987, 2001, 2013, and 2017 (Table 1). The chosen images were acquired during February and March-except for 2013-which represent the dry season with least cloud cover. All of those images have the following characteristics: Projection: UTM Zone 33, Spheroid: WGS 84, Datum: WGS 84.

\subsection{Pre-Processing}

All images were pre-processed. ENVI 5.3 software is used for pre-processing the images, including Radiometric calibration and atmospheric correction, performing post-processing (supervised classification), and calculating the classes areas. ArcGIS 10.2 software was used to create the final maps. Atmospheric correction was conducted using the Fast Line-of-Sight Atmospheric Analysis of Spectral Hypercubes (FLAASH) module in ENVI 5.3 after the calibration of the digital numbers of the images to surface reflectance values. ArcGIS 10.2 software was used to convert the raster data to vector data, extract the water surface area, 
and to create the final maps.

One image could not cover the whole lake, so the mosaic tool In ENVI 5.3 software has been used to create a single image for the whole lake for every chosen year (Figure 4).

\subsection{Analysis}

\section{Classification Methods}

The main purpose of images classification in remote sensing is to generate land

Table 1. Characteristics of the satellite imagery used in this paper.

\begin{tabular}{cccc}
\hline No & data & Acquisition date & Path/row \\
\hline 1 & Landsat 1 Multi-Spectral (MSS) & 18 Feb/07, 26 Mar 1973 & $198,199 / 50,51$ \\
2 & Landsat 5 Thematic Mapper (TM) & $13,20,27$ Mar 1987 & $184,185,186 / 50,51$ \\
3 & Landsat 7 Enhanced Thematic Mapper Plus (ETM+) & $5,7,14$ Feb 2001 & $184,185,186 / 50,51$ \\
4 & Landsat 8 Operational Land Imager (OLI) and Thermal Infrared Sensor (TIRS) & $12 / 4,23 / 5$ 2013 & $184,185,186 / 50,51$ \\
5 & Landsat 8 Operational Land Imager (OLI) and Thermal Infrared Sensor (TIRS) & $22,29,31$ Mar 2017 & $184,185,186 / 50,51$ \\
\hline
\end{tabular}

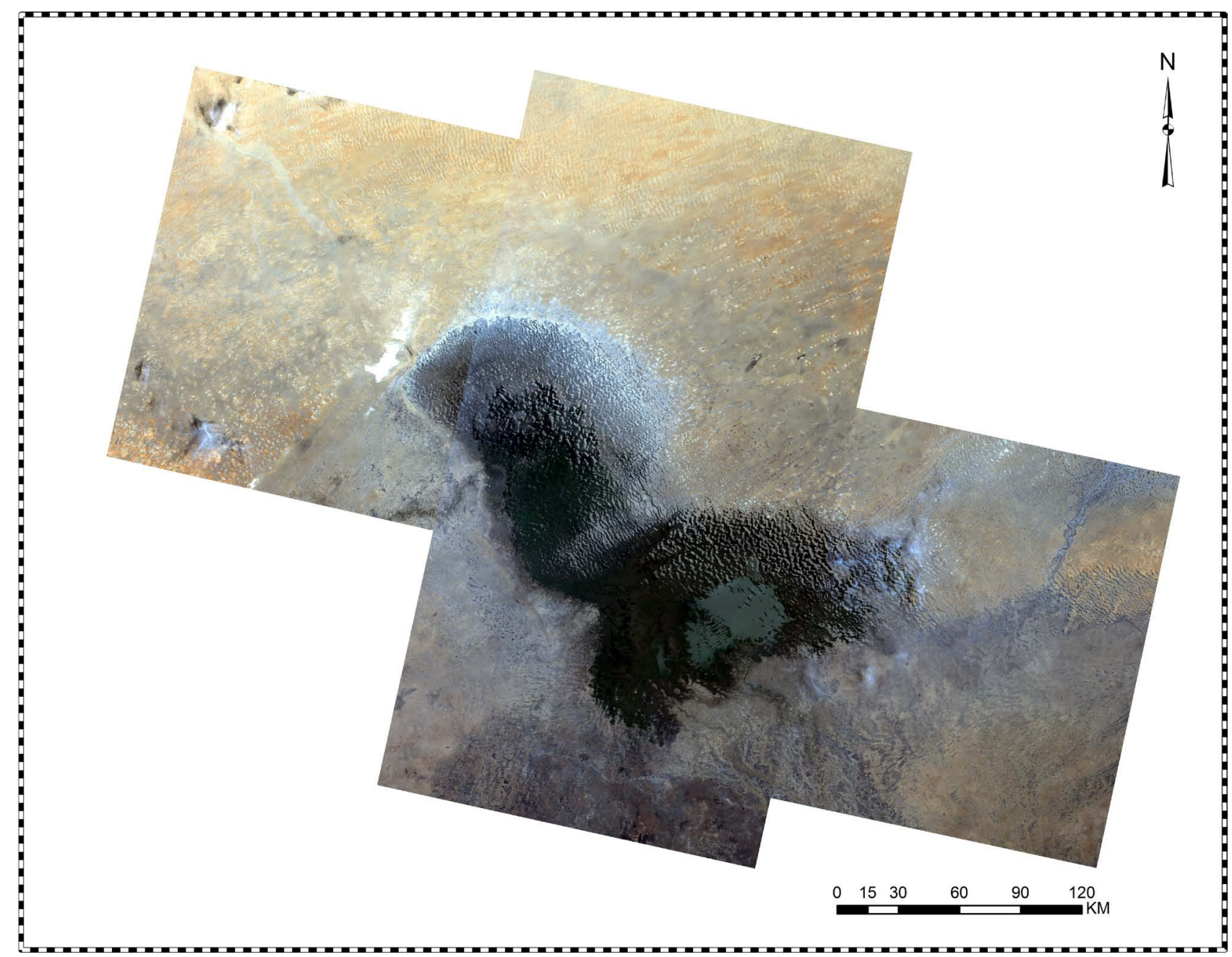

Figure 4. Mosaicked image of Lake Chad acquired in 2017. 
cover classes or themes. Two types of classification had been conducted to reach the desired results:

1) Unsupervised classification

2) Supervised classification

The "Iso-Data" and the "Supervised Maximum Likelihood" methods had been conducted for the unsupervised and supervised classification, respectively, to identify the open water body class. The lake and its surrounding were divided into two classes (i.e. water and non-water surface) using the supervised maximum likelihood method. Then these classes were converted from raster to vector data. For the supervised classification, high resolution Google earth images have been used to select the training sites. Figure 5 shows the flow diagram of the methodology.

\section{Results and Discussion}

The analyzed remote sensing data showed an enormous decrease in Lake Chad surface water from 1973 to 2017. The supervised classification of Lake Chad for the year 1973 Showed that the open water area was covering $16,157.4 \mathrm{~km}^{2}$, while it decreased dramatically in 1987, to reach only $1495.99 \mathrm{~km}^{2}$. The water covered only the southern pool, while the northern pool become totally dry. The total water surface area started to increase reaching $3712.74 \mathrm{~km}^{2}$ in 2001, and the water started to cover the northern pool partially. Unfortunately, this rise did not last, as the total water surface area reached $2686.5 \mathrm{~km}^{2}$ in 2013, divided between the two pools. The decrease continued in the following years to reach $1831.4 \mathrm{~km}^{2}$ in 2017. In 2017, the lake lost about $88.77 \%$ of its water. The percentage of the water surface area fluctuated during the different periods. In the first period (1973 to 1987) the water surface area decreased severely as the lake lost in this period about $90.7 \%$ of its water, with only $9.26 \%$ of the lake was covered with water. The total water surface area increased during the period of 1987 to 2001 to reach $22.98 \%$. From 2001 to 2013 the surface water area decreased again to reach about $16.62 \%$. The decrease continued in 2013 to 2017 period. The lake was covered by only $11.33 \%$ of open water comparing to 1973 (Table 2) (Figures 6(a)-(e) \& Figure 7).

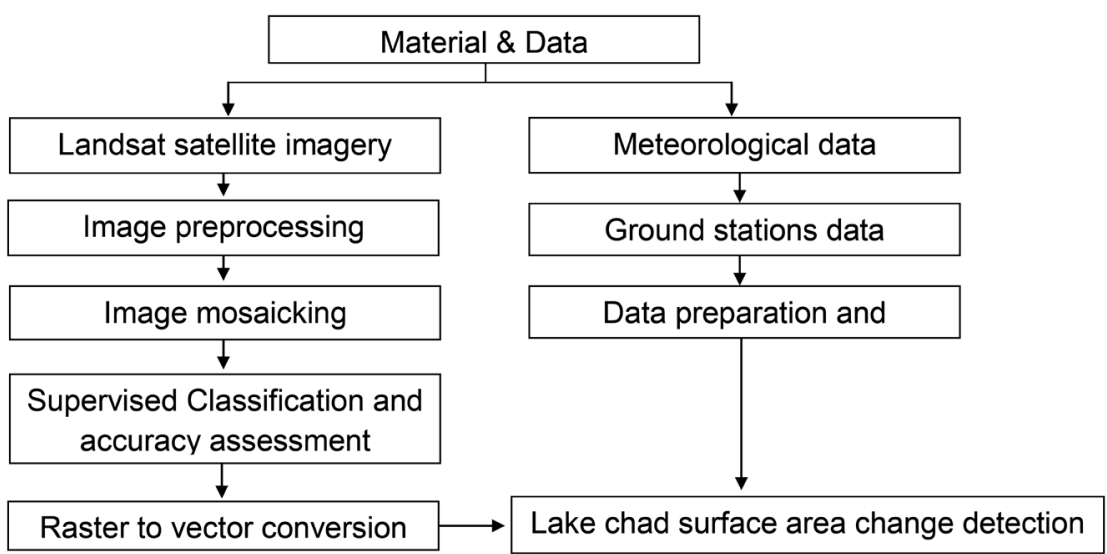

Figure 5. Flow diagram of methodology. 
The records of N'djamena station for the mean volume of the water discharge to the lake from the feeding rivers during the years of 2012 and 2016 showed significant decline in 2016 compared to 2012 [26] (Figure 8). This could be attributed to that the rainfall over the whole basin which flows to channels and rivers and on which the water discharge of these rivers depends has also significantly declined in year 2016 compared to year 2012. Accordingly, the continued decrease in the water surface area of Lake Chad from 2013 to 2017 is believed to be due to the fluctuation in the annual rainfall averages, which adversely affected the total surface water flowing to the feeding rivers and in turn the total discharge to the lake.

Table 2. Lake Chad water surface area change during the period from 1973-2017.

\begin{tabular}{ccc}
\hline Year & $\begin{array}{c}\text { Water surface area } \\
\left(\mathrm{Km}^{2}\right)\end{array}$ & $\begin{array}{c}\text { Water surface area } \\
(\%)\end{array}$ \\
\hline 1973 & $16,157.4$ & 100 \\
1987 & $14,95.99$ & 9.26 \\
2001 & 3712.74 & 22.98 \\
2013 & 2686.5 & 16.62 \\
2017 & 1831.44 & 11.33 \\
\hline
\end{tabular}

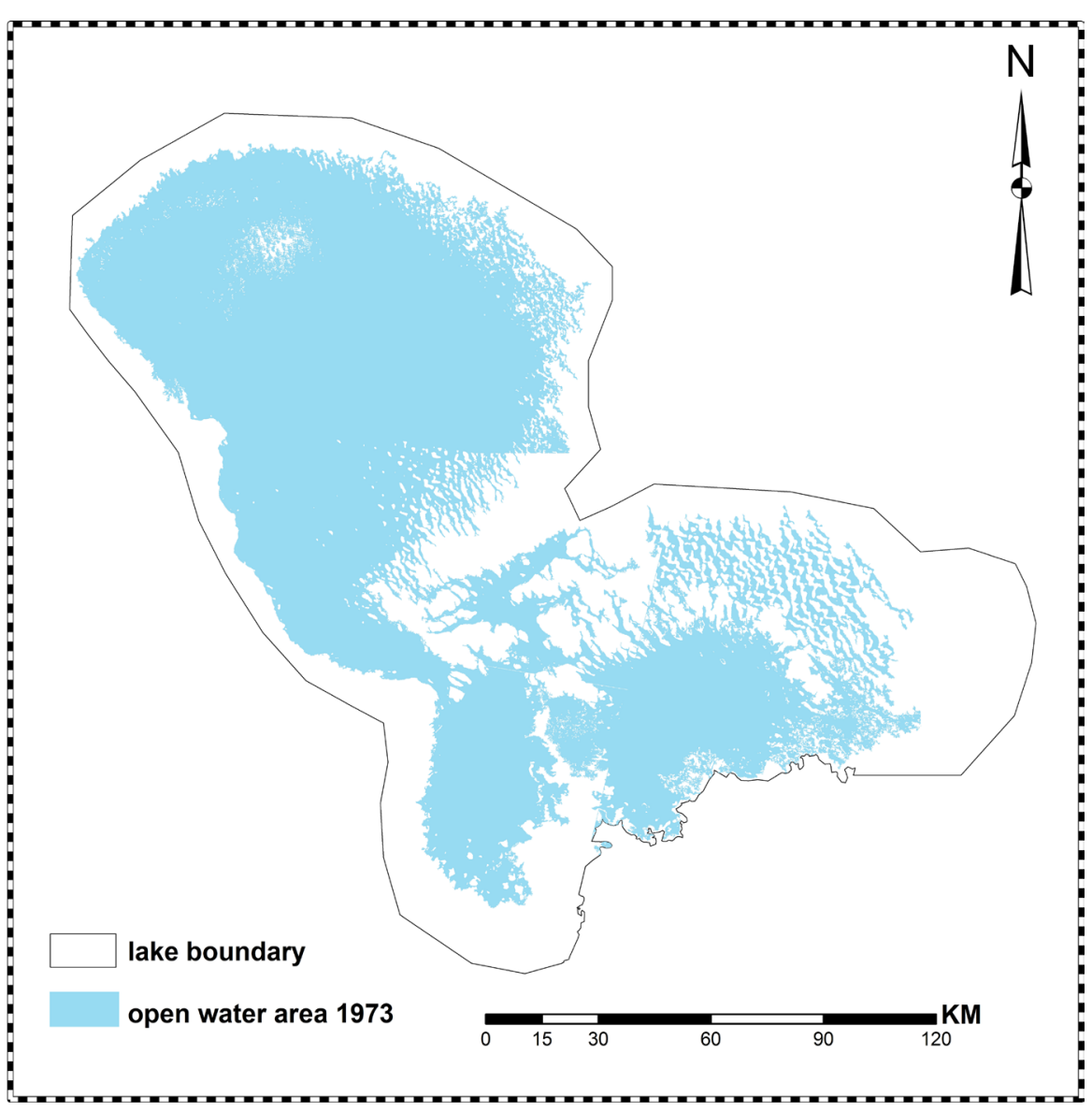

(a) 
A.-A. A. Mahamat et al.

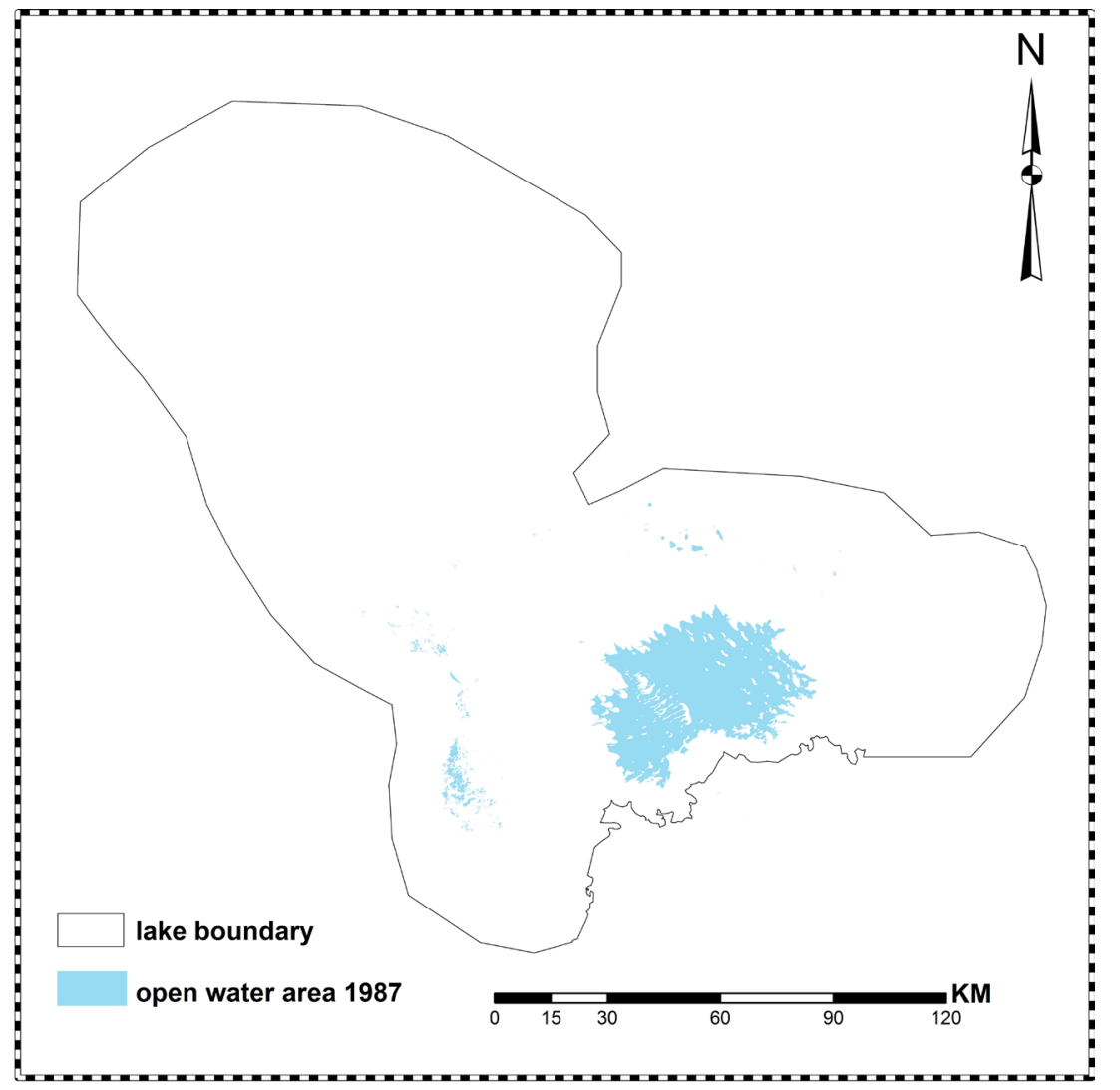

(b)

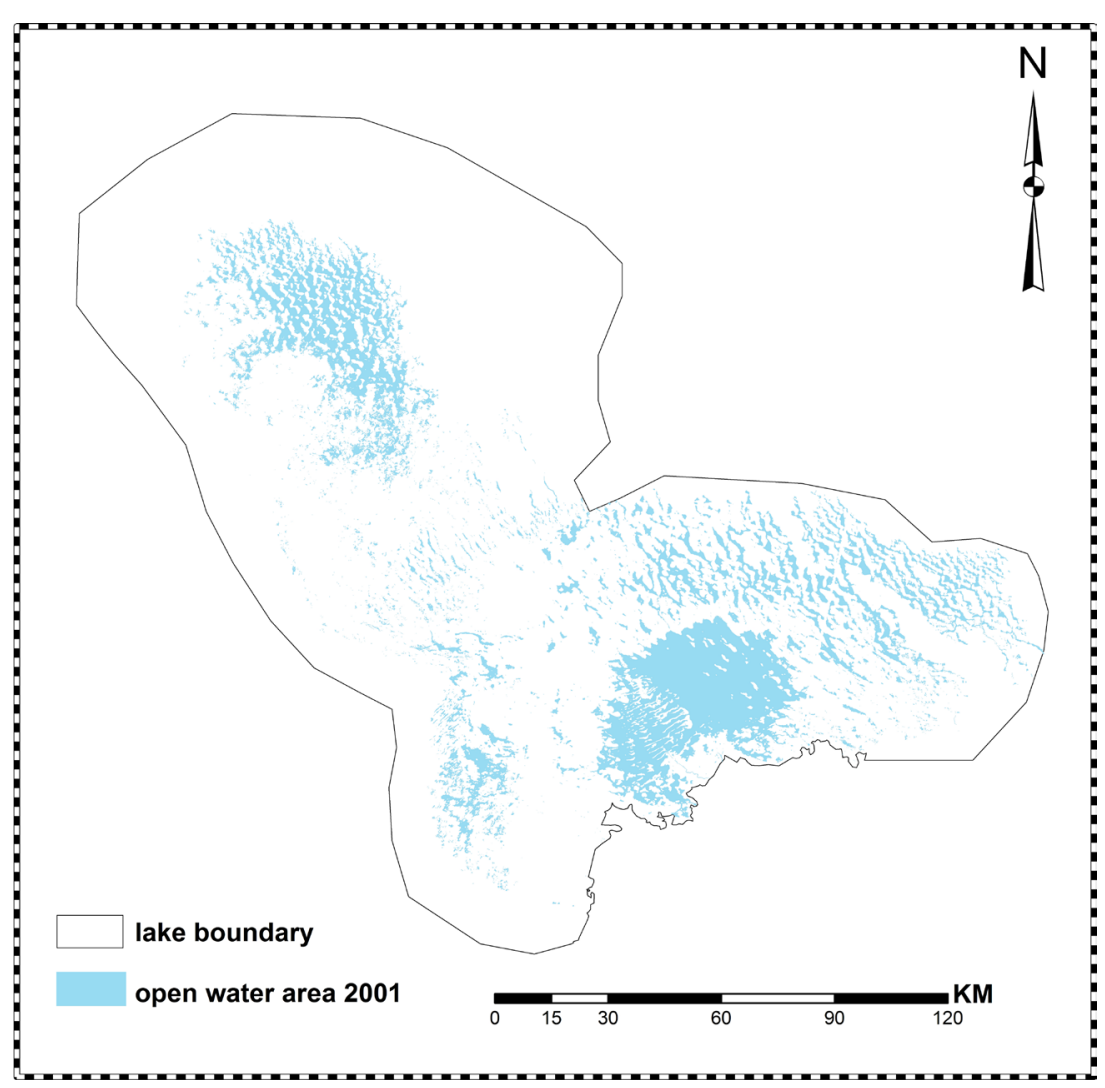

(c) 


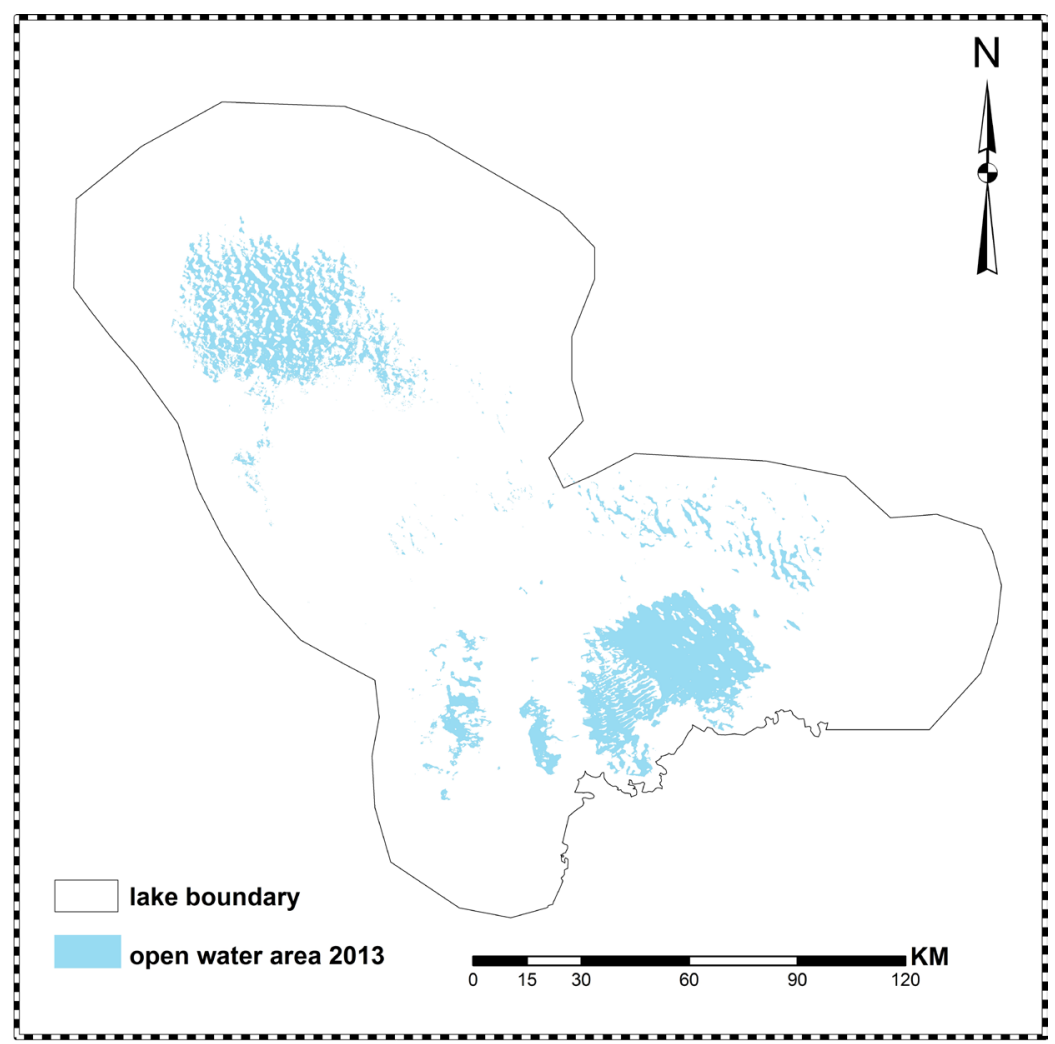

(d)

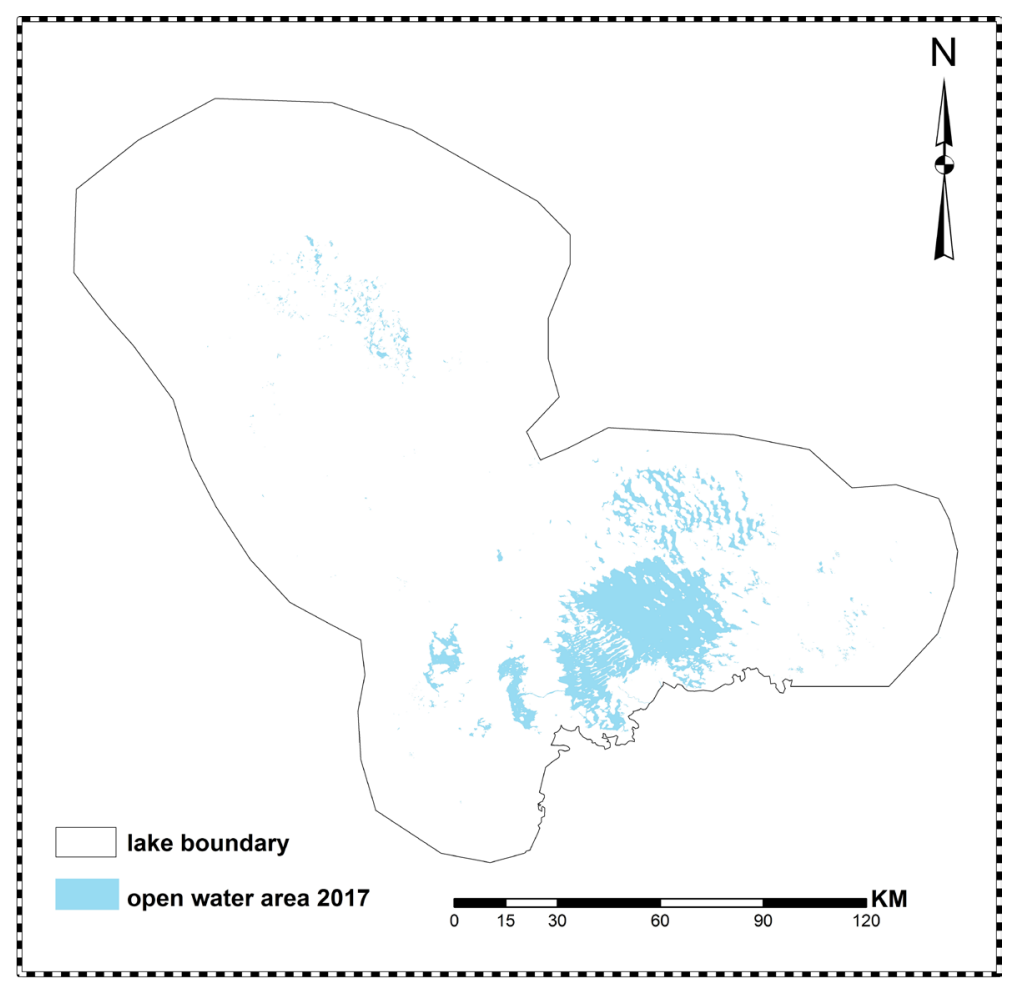

(e)

Figure 6. Serial maps of Lake Chad showing change of water surface area in different years through the period (1973-2017): (a) 1973; (b) 1987; (c) 2001; (d) 2013; and (e) 2017, using supervised classification technique. 


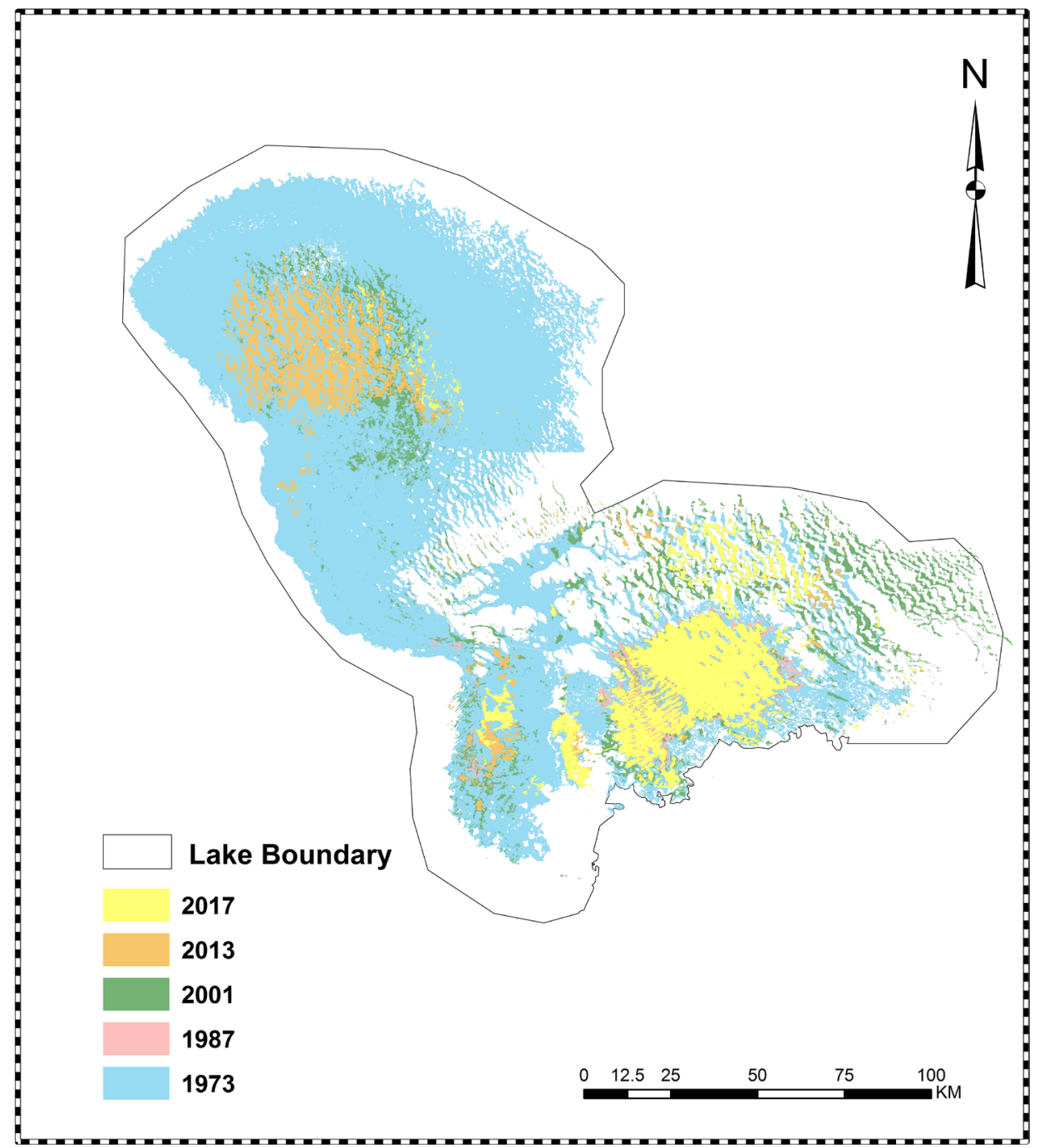

Figure 7. A map showing the change detected in the open surface water covering Lake Chad during the period (1973-2017), using supervised classification technique.

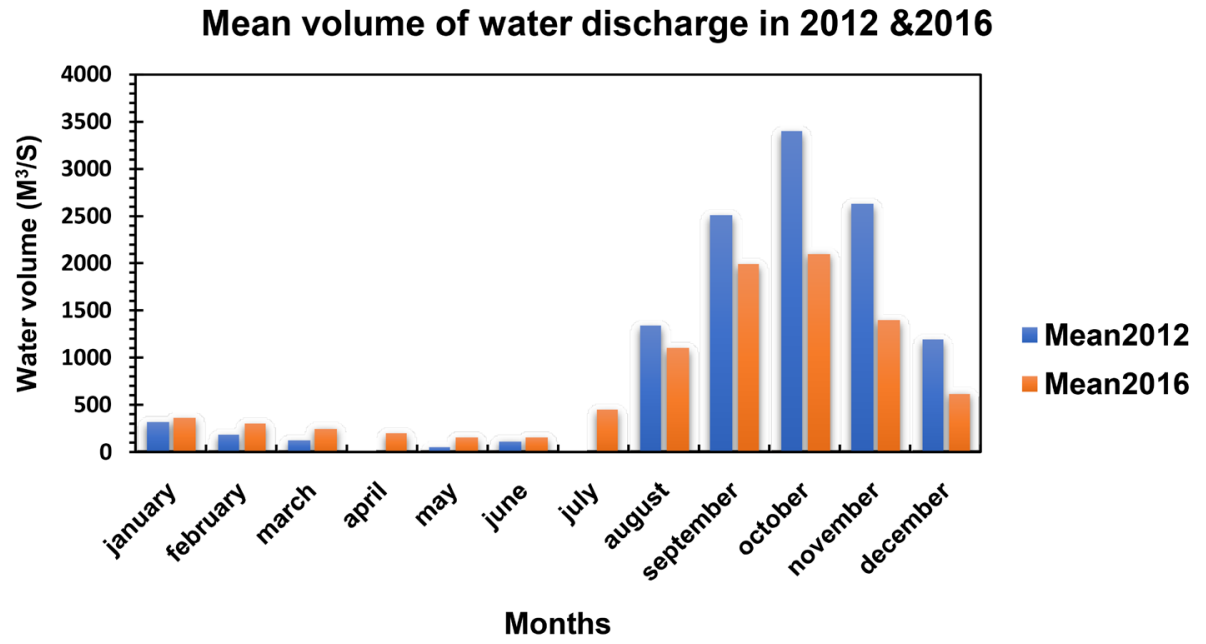

Figure 8. A chart showing the decline in the mean volume of water discharge in N'djamena station in year 2016 compared to year 2012. 


\section{Conclusions}

Applying GIS and remote sensing techniques through landsat satellite imagery is a mandatory and appropriate method to be used in estimating and assessing the status of environmentally deteriorating areas when the available data from ground monitoring stations are inaccessible, insufficient, deficient or missing crucial data series, such as the case in Lake Chad basin that suffers from retreating of the water surface area. The prepared maps of Lake Chad using landsat satellite imagery throughout the study period (1973-2017) made it achievable to detect the changes in the water surface area and the lake boundary variation throughout the study period, as the water surface area was dramatically decreasing.

By correlating the few available and limited meteorological data on the fluctuating rainfall and precipitation that resulted in severe drought period that the lake Chad basin witnessed in the mid 1973 to 1980s and recurrently continued to 2017, with the prepared maps it was concluded that the drought was the major contributor to the deterioration of the lake Chad throughout the study period, due to the significant impact both on the water inflow the lake from the rivers supplying the Lake (Chari and Logon) and on the recharge of groundwater aquifers, which was reflected in the prepared maps showing the resulted shrinkage of the water surface area of the lake Chad and lake's boundary fluctuation from small to dry lake.

Beside the climate change and global warming of which the severe drought period was an ultimate result, other factors also contributed to the current status of Lake Chad including the absence or inadequate integrated water resources management in the countries sharing the lake, unsustainable development programs, gaps in the monitoring data series due to the dilapidated state of the meteorological monitoring stations, the security situation prevailing the countries sharing the lake and in vicinity of Lake Chad that intensively lowered the level of their technical services, and the inaccessibility to most of the data resource on the lake. These factors collectively made it difficult for the decision makers or planners to adopt an environmentally sound approach in the area and prompted researchers to utilize other more sufficient techniques, e.g., GIS and remote sensing techniques that are capable to overcome such obstacles and facilitate in assessing and rehabilitating the ecosystems in similar cases of environmentally deteriorating areas.

\section{Recommendations}

Although the dilemma of Lake Chad is a result of a mixture of complicated natural and anthropogenic processes and factors that seem, at the first site, unavoidable and their impacts are irreversible or cannot be overcome, there might be some scenarios or approaches suggested to reduce or mitigate such impacts:

1) When planning for any developmental program on any area its environmental, scientific, and socioeconomic significance, the climatological, hydrological, geological and physical settings of the targeted area, as well as, the existence 
of any vital natural resources, should be taken into consideration and the impacts of such programs either they would be negatively or positively affecting the area should be investigated thoroughly.

2) For any proposed projects in an area, an environmental impact assessment (EIA) study should be conducted as a pre-requisite for approving such projects as for the decision makers to take the appropriate and environmentally sound decision.

3) There should be specific legislations that would protect, prevent, and prohibit any projects or programs that would adversely affect areas of universal significance.

4) Propose mitigation measures that might have a positive effect in reducing the adverse impacts from either natural processes or anthropogenic activities on the natural resources and wealth of the targeted areas, e.g. in the case of Lake Chad, water harvesting projects, integrated water resources management of the major rivers feeding the lake, controlling overexploitation of water in the vicinity of the study area and conventions/agreements among the countries in which the major rivers feeding the lake are flowing through, where such conventions/ agreements provide the organized and sustainable use of the flowing water.

5) The Lake Chad Basin is regarded as a transboundary basin that suffered and still suffering from climate change including high temperature ranges and evaporation rates and severe weather conditions like recurrent droughts. Therefore, integrated management and balanced planning are vital to be applied in Lake Chad Basin taking into account, beside the different socio-economic sectors, the transhumance and migration, which would make a considerable load on the available resources.

\section{Acknowledgements}

The authors thank the US Geological Survey (USGS) and the Lake Chad Basin Commission (LCBC) for the freely available data that been used in this paper.

\section{Conflicts of Interest}

The authors declare no conflicts of interest regarding the publication of this paper.

\section{References}

[1] http://www.usgs.gov

[2] Sarch, M. (2001) Fishing and Farming at Lake Chad: Institutions for Access to Natural Resources. Journal of Environmental Management, 62, 185-199. https://doi.org/10.1006/jema.2001.0430

[3] Grove, A.T. (1996) African River Discharges and Lake Levels in the Twentieth Century. In: The Limnology Climatology and Paleoclimatology of the East African Lakes, Gordon \& Breach Science Publishers, Amsterdam, 95-100. https://doi.org/10.1201/9780203748978-5

[4] Margin, G. (2016) The Disappearance of Lake Chad: History of a Myth. Journal of 
Political Ecology, 23, 204-222. https://doi.org/10.2458/v23i1.20191

[5] Zhu, W., Jia, S., Lall, U., Cao, Q. and Mahmood, R. (2019) Relative Contribution of Climate Variability and Human Activities on the Water Loss of the Chari/Logone River Discharge into Lake Chad: A Conceptual and Statistical Approach. Journal of Hydrology, 569, 519-531. https://doi.org/10.1016/j.jhydrol.2018.12.015

[6] Babama'aji, R.A. (2013) Impacts of Precipitation, Land Use Land Cover and Soil Type on the Water Balance of Lake Chad Basin.

[7] Olivry, J.-C., Chouret, A., Vuillaume, G., Lemoalle, J. and Bricquet, J.-P. (1996) Hydrologie Du Lac Tchad.

[8] Tilho, J. (1928) Variations et disparition possible du Tchad. Annales de géographie, 37, 238-260. https://doi.org/10.3406/geo.1928.9299

[9] Lemoalle, J., Bader, J.-C., Leblanc, M. and Sedick, A. (2012) Recent Changes in Lake Chad: Observations, Simulations and Management Options (1973-2011). Global and Planetary Change, 80-81, 247-254. https://doi.org/10.1016/j.gloplacha.2011.07.004

[10] Schuster, M., Roquin, C., Brunet, M., Duringer, P.H., Fontugne, M., Mackaye, H.T., Vignaud, P. and Ghienne, J.-F. (2005) Highlighting Holocene Lake Mega-Chad Paleoshorelines from Space. Quaternary Science Reviews, 24, 1821-1827. https://doi.org/10.1016/j.quascirev.2005.02.001

[11] Burke, K. (1976) The Chad Basin: An Active Intra-Continental Basin. Tectonophysics, 36, 197-206. https://doi.org/10.1016/0040-1951(76)90016-0

[12] Ghienne, J.-F., Schuster, M., Bernard, A., Duringer, P. and Brunetc, M. (2002) The Holocene Giant Lake Chad Revealed by Digital Elevation Models. Quaternary International, 87, 81-85. https://doi.org/10.1016/S1040-6182(01)00063-5

[13] Schuster, M., Duringer, P., Ghienne, J.-F., Vignaud, P., Beauvilain, A., Taisso, H.M., and Brunet, M. (2003) Coastal Conglomerates around the Hadjer el Khamis Inselbergs (Western Chad, Central Africa): New Evidence for Lake Mega-Chad Episodes. Earth Surface Processes and Landforms, 28, 1059-1069. https://doi.org/10.1002/esp.502

[14] Durand, A. (1982) Oscillations of Lake Chad over the Past 50000 Years: New Data and Hypothesis. Palaeogeography, Palaeoclimatology, Palaeoecology, 16, 37-53. https://doi.org/10.1016/0031-0182(82)90071-2

[15] Vassolo, S. (2012) Ground Water Need Assessment Lake Chad Basin. Report.

[16] IAEA (2017) Integrated and Sustainable Management of Shared Aquifer Systems and Basins of the Sahel Region. Report of the IAEA-Supported Regional Technical Cooperation Project RAF/7/011.

[17] Reis, S. and Yilmaz, H.M. (2008) Temporal Monitoring of Water Level Changes in Seyfe Lake Using Remote Sensing. Hydrological Processes, 22, 4448-4454. https://doi.org/10.1002/hyp.7047

[18] Ginzburg, A.I., Andrey, G., Kostianoy, N.A.S. and Valentina, I.K. (2010) Satellite Monitoring of the Aral Sea Region. In: The Aral Sea Environment, Springer, Berlin, 147-179. https://doi.org/10.1007/698_2009_15

[19] Changwony, C., Sichangi, A.W. and Ngigi, M.M. (2017) Using GIS and Remote Sensing in Assessment of Water Scarcity in Nakuru County, Kenya. Advances in Remote Sensing, 6, 88-102. https://doi.org/10.4236/ars.2017.61007

[20] Giardino, C., Bresciani, M., Villa, P. and Martinelli, A. (2010) Application of Remote Sensing in Water Resource Management: The Case Study of Lake Trasimeno, Italy. Water Resources Management, 24, 3885-3899. 
https://doi.org/10.1007/s11269-010-9639-3

[21] Dörnhöfer, K. and Oppelt, N. (2016) Remote Sensing for Lake Research and Monitoring-Recent Advances. Ecological Indicators, 64, 105-122. https://doi.org/10.1016/j.ecolind.2015.12.009

[22] UNEP (2006) Africa's Lakes: Atlas of Our Changing Environment. United Nations Environment Programme, Division of Early Warning and Assessment (DEWA) EarthPrint, Nairobi, 90 p. https://na.unep.net/atlas/africaLakes/book.php

[23] Birkett, C.M. (2000) Synergistic Remote Sensing of Lake Chad: Variability of Basin Inundation. Remote Sensing Environment, 72, 218-236.

https://doi.org/10.1016/S0034-4257(99)00105-4

[24] Leblanc, M., Lemoalle, J., Bader, J.-C., Tweed, S. and Mofor, L. (2011) Thermal Remote Sensing of Water under Flooded Vegetation: New Observations of Inundation Patterns for the "Small” Lake Chad. Journal of Hydrology, 404, 87-98. https://doi.org/10.1016/j.jhydrol.2011.04.023

[25] Policelli, F., Hubbard, A., Jung, H.C., Zaitchik, B. and Ichok, C. (2018) Lake Chad Total Surface Water Area as Derived from Land Surface Temperature and Radar Remote Sensing Data. Remote Sensing, 10, 252. https://doi.org/10.3390/rs10020252

[26] Lake Chad Basin Commission. https://lis.cblt.org/lis/water/surface/discharge 